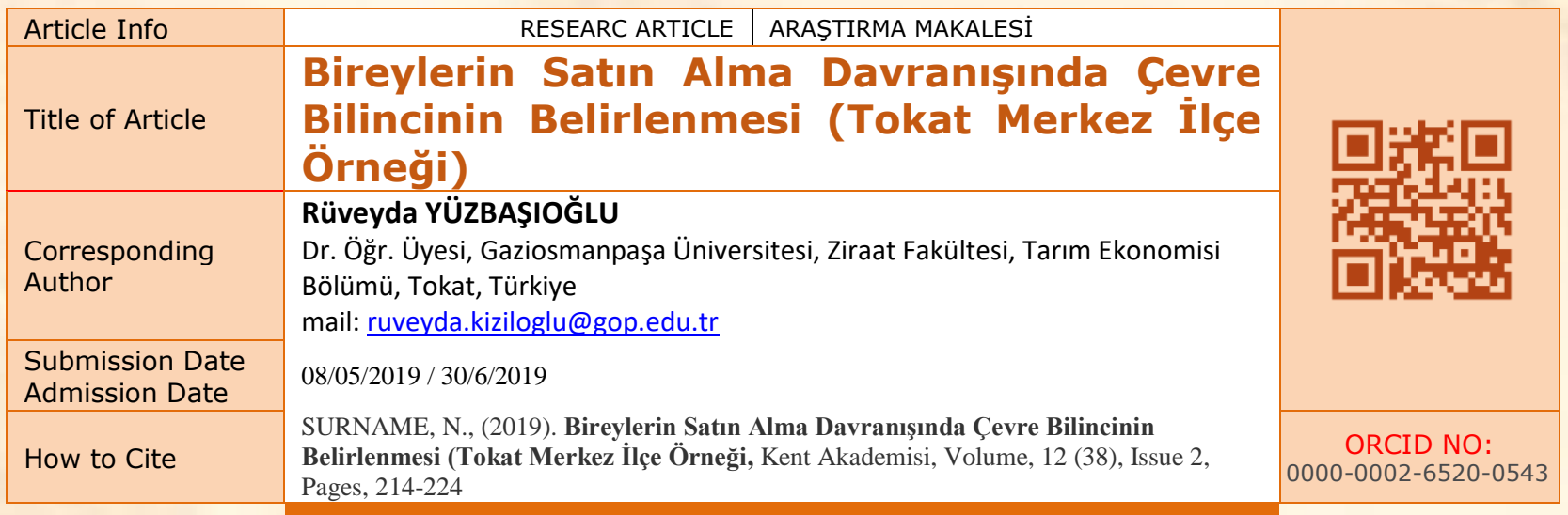

\title{
Bireylerin Satın Alma Davranışında Çevre Bilincinin Belirlenmesi (Tokat Merkez İlçe Örneği)
}

\section{Determination of environmental awareness in purchasing behavior of individuals (The Case of Tokat Central Country)}

\section{ABSTRACT}

After examining the socio-demographic characteristics of individuals, a number of questions were asked about the levels of awareness in the acquisition and the scoring system of the questions was applied. In terms of this scoring, $69.45 \%$ of individuals were designed to have high levels of consciousness.

It has been observed that the individuals have the sensitivity to read the environmental issues, the insignificance about the environmental issues, the importance of separating the garbage and the fact that they are packaged. It can be said that individuals know that they know recycled products. You need to be aware of the environmental pollution of individuals, but it is necessary to say that you do not extend information about the necessary information, that is, individuals have the potential to be conscious of environmental issues.

Keywords: Environmental awareness, Environmental sensitivity, Behavior, Purchasing, Attitude

\footnotetext{
${ }^{1}$ Dr. Öğr. Üyesi Gaziosmanpaşa Üniversitesi, Ziraat Fakültesi, Tarım Ekonomisi Bölümü, Tokat, Türkiye e-mail: ruveyda.kiziloglu@gop.edu.tr

2 Dr. Arş.Gör. Gaziosmanpaşa Üniversitesi, Ziraat Fakültesi, Tarım Ekonomisi Bölümü, Tokat, Türkiye e-mail: esra.gurel@gop.edu.tr
} 


\section{ÖZET}

Globalleşen dünyada, çevreye ilişkin problemlerin artış göstermesi, çevreci ürünlere olan ilgi duyarlılığını da beraberinde getirmektedir. Bu bağlamda bireylerin satın alma davranışlarındaki çevre bilincini ortaya koymak amacıyla çalışma çok yönlü incelenerek istatistiki olarak değerlendirmeler yapılmıştır. $\mathrm{Bu}$ amaç doğrultusunda bireylerin sosyo-demografik özellikleri incelendikten sonra, satın almadaki bilinç düzeylerini belirlemek için bir takım sorular sorulmuş ve soruların puanlama sistemi uygulanmıştır. Bu puanlama sonucu bireylerin \%69.45'i bilinç seviyesi yüksek olarak belirlenmiştir.

Bireylerin çevre konularına önem verdiği, çevreye ilişkin haberleri izlediği, çöplerini ayrıştırma konusunda önem gösterdikleri ve ambalajlı ürünlerin etiketlerini okuma hassasiyeti olduğu gözlenmiştir. Bireylerin geri dönüşümlü ürünleri bildiği tanıdığı söylenebilir. Bireylerin çevre kirliliğine ilişkin farkında olunduğunun ancak korunması gereken bilgiler hakkında bilgi eksiliğinin olduğunun, yani bireylerin çevre konularında bilinçli olma potansiyeli olduğu araştırma sonuçları doğrultusunda söylenebilir.

Anahtar Kelimeler: Çevre bilinci, Çevre duyarlılığı, Davranış, Satın alma, Tutum

\section{GíRISs:}

Çevre kirliliği artık bütün dünya da kabul görmüş bir gerçektir. Son yıllarda insanoğlunun geleceği için çevre kirliliği ve onun olumsuz bir sonucu olan küresel isınmayla ilgili endişeler artmaktadır. Gelecek nesillere tükenmiş kaynaklar bırakmamak için satın alınan her üründe bilinçli olmak kıt doğal kaynakların korunması önemli bir unsurdur. Bu araştırmada bireylerin satın alımındaki çevre bilinci ölçmenin yanında kaynakları korumak, sürdürülebilir bir çevre için gerekli önemlerin alınması ve ileriye dönük önerilerde bulunarak yeşil bir çevre için gelecek çalışmalara 1şık tutmaktır. Bu bağlamda araştırma 5 bölümden oluşturulmuştur. İlk bölümde bireylerin sosyo-ekonomik yapısı incelenmiştir. İkinci bölümde bireylerin satın almada ki bilinç düzeyleri belirlenmiş, üçüncü bölümde bireylerin satın alımındaki tutum ve davranışlarını belirlemek için faktör analizi yapılmış ve satın almada bilinç düzeyini etkileyen faktörlerin belirlenmesi üzere binary logit analizi yapılmıştır.

Zengin korunmuş kaynakların gelecek nesillere bırakabilinmesi için çevre kirliliğinin önlenebilmesi çok önemlidir. Bunun içinde bireylerin tükettiği her bir ürün çevreci olunursa kısmen tedbir alınmış olunur. Literatürde çevre kirliliği ya da çevre kirliliğini önlenmesi ile alakalı yeşil ürün kullanımı üzerine çalışmalara rastlamak mümkündür. Bu kapsamdaki çalışmalar da yapılan araştırmalar, bireylerin çevre bilinci veya yeşil ürün satın alması üzerine; Çabuk ve ark. (2008), Yeniçeri (2008), Aracioğlu ve Tatlıdil (2009), Yaraş ve ark. (2011), Duru ve Şua (2013), Armağan ve Karatürk (2014), Buğday ve Babaoğul (2016), Tayfun ve Öçlü (2016), Yıldız ve Barut (2016), Benli ve ark. (2017), Korkmaz ve ark. (2017) ve Onurlubaş ve ark. (2017a-b)'dir. Öğrencilerin yeşil ürün satın alması ya da çevre duyarlılığı üzerine yakın zamanda yapılımış araştırmalar incelendiğinde ise; Türkmen ve ark. (2013) ve Alkaya ve ark. (2016)'dır.

Yabancı literatürde incelendiğinde; Biswas ve Roy (2015), Khare (2015) ve Yadav ve Pathak (2016) ekonomisi gelişmekte olan doğu ülkelerindeki tüketiciler üzerinde yaptıkları araştırmalarında yeşil ürün satın alma eğilimlerini belirlemeye çalışmışlardır. Çevre dostu olan yeşil ürün satın almada tüketici davranışlarını inceleyen son zamandaki çalışmalara da rastlamak münkün; Liobikien ve ark. (2016), Maichum ve ark. (2016), Medeiros ve ark. (2016) ve Suki (2016) gibi çalışmalar literatürde mevcuttur.

Ancak yerli ve yabancı literatürler detaylı olarak incelendiğinde bireylerin çevre bilincini belirleyici, çevreye karşı tutumlarını sınıflandıracak ve satın almayı etkileyen faktörlerin bir arada inceleyen araştırmaya rastlanmaması bu araştırmanın önemini artırmaktadır. 


\section{MATERYAL VE YÖNTEM:}

\section{Materyal}

Bu araştırmanın materyalini, Tokat ili merkez ilçede kentsel alanda bulunan bireylerden anket yoluyla elde edilen veriler oluşturmuşstur.

\section{Verilerin Toplanması Aşamasında İzlenen Yöntem}

Ana kitlenin en iyi düzeyde temsil edilecek örnek sayısının belirlenmesinde oransal yaklaşımdan yararlanılmıştır (Yamane, 2001).

$$
\mathrm{n}=\frac{N p(1-p)}{(N-1) \sigma_{p}^{2}+p(1-p)}
$$

$\mathrm{n}=$ örnek büyüklüğ̈̈,

$\mathrm{N}=$ populasyon büyüklüğü,

p= tahmin oranı (0.5 maksimum örnek büyüklüğü için),

$\sigma_{p}^{2}=$ oran varyansı (maksimum örnek hacmine ulaşmak için \%95 güven aralığında Çizelge değeri 1.96 ve \%5 hata payı ile). Ana kitleyi oluşturan bireylerin özellikleri başlangıçta bilinmediği için, örnek hacmini maksimum kılacak şekilde $\mathrm{p}=0.5$ olarak alınmış ve örnek hacmi 383 birey olarak bulunmuştur. Görüşülecek bireylerin sayısının belirlenmesinde, yerleşim birimlerinin toplam popülasyon içindeki payları esas alınmış (Kızıloğlu ve Kızılaslan, 2013) ve örneğe alınan bireyler tesadüfi olarak belirlenmiştir.

\section{Verilerin Analizi Aşamasında İzlenen Yöntem}

Bireylerin 5'li likert ölçeği kullanılarak çevre duyarlılığı belirlenmek istenmiştir. Bireylerin çevre duyarlılığına karş1 satın almadaki bilgi, tutum ve danışlarını belirlemek için faktör analizi uygulanmıştır. Faktör analizi, değişkenler arasındaki ilişkilere dayanarak verilerin daha anlamlı ve özet bir biçimde sunulmasını sağlayan birçok değişkenli istatistiksel analiz türüdür (Kurtuluş 2004; Tekin 2007; Karpati ve Szakal 2009). Bu analizin temel amac1, orijinal değişkenler arasındaki ilişkiyi en az bilgi kaybıyla bir grup faktör ile açıklayarak her bir faktörü teker teker yorumlamaktır. Kısaca faktör analizi, özgün bilgiyi olabildiğince koruyarak daha az veri ile çalışmayı mümkün kılmaktadır. Kişilerin bir konu ile ilgili davranışını tek bir soruyla ölçmek çoğu zaman mümkün olmamaktadır. Bu davranışı etkileyen birçok faktörün birbiriyle yakın bağlantısı vardır. Faktör analizinin amacı bilgi kaybını olabildiğince azaltarak bu yakın faktörleri bir araya getirerek daha az faktörle çalışmaya imkan sağlamaktadır (Ness, 2000; Kızıloğlu ve ark., 2013).

Ölçeklendirilen satın alma davranışını ve tutumlarını gösteren durumlar sayıca fazla olduğu için açıklayıcı değişken olarak her birinin kullanılması mümkün değildir. Bu nedenle, değişkenlerin özet halde gösterilmesi gerekmektedir. Araştırmada değişkenlerin özetlenmesi faktör analizi yardımı ile yapılmıştır ve binary logit analizinde açıklayıcı değişken olarak bu faktörler kullanılmıştır (Dölekoğlu ve Yurdakul, 2004).

Bireylerin satın almadaki bilinç düzeylerini belirlemek için bir takım (Çevre Kirliliği konusuna önem verme, Çevreye ilişskin haberleri izleme, çevre kirliliğine ilişkin konuları sınıflandırma, çöp ayrıştırması, ambalaj veya etiket üzerindeki bilgileri okuma ve geri dönüşümü olan maddeler) sorular hazırlanmıştır. Her bir soruya puan verilmiştir. 19 ham puan hesaplanmıştır. Ham puanın yarısının altında puan alanlar bilinç seviyesi düşük olanlar, yarısından yukarı puan alan bireyler bilinçli bireyler olarak belirlenmiştir. Böylelikle binary logit analizinin bağımlı değişkeni belirlenmiştir. Bireylerin satın almadaki bilinç seviyesini etkileyen faktörlerin analizi için binary logit analizi uygulanmıştır.

Logit modelinde bağımlı değişken Dummy ve tahmin edilen olasılık değerleri 0 ile 1 arasında değişmektedir. 
Lojistik modelde yer alan bazı değişkenler, kategoriler arası farklılıkları olasılık oranları olarak elde edilebilmek üzere kategorik değişkene çevrilmiştir. Yorumlamada kolaylık sağlaması açısından bağımsız değişkenlerin bazıları dummy değişken olarak modele alınmıştır.

Modele açıklayıcı değişkenler olarak; bireylerin yas1 (eğer bireyler 30 ve altı yaş grubunda ise: 1 değil ise:0 olarak kodlanmıştır), yas2 (eğer bireyler 31-40 yaş grubunda ise:1 değil ise:0 olarak kodlanmıştır), yas3 (eğer bireyler 41 ve üzeri yaş grubunda ise: 1 değil ise:0 olarak kodlanmıştır), cinsiyet (bayan ise 0 , erkek ise 1 olarak kodlanmıştır), medeni durum (bekar ise 0 , evli ise 1 olarak kodlanmıştır), eğitim durumu(lise ve lise altı ise 0 , lise üstü ise 1 olarak kodlanmıştır), çalışma durumu (çalışmıyorsa veya bekar ise 0 , çalışıyorsa ise 1 olarak kodlanmıştır), eşinin eğitim durumu lise ve lise altı ise 0 , lise üstü ise 1 olarak kodlanmıştır), eşinin çalışma durumu (çalışmıyorsa veya bekar ise 0 , çalışıyorsa ise 1 olarak kodlanmıştır), fert sayısı (sürekli değişken), bireylerin aylık gelir grubu (eğer bireylerin aylık geliri 2.500 ay/TL'nin üstünde ise:1 2.500 ve altında ise:0 olarak kodlanmıştır), tasarruf (faktör 1 , sürekli değiş̧en), çevre bilinci ve duyarlılığ (faktör 2, sürekli değişken), satın alma bilinci (faktör 3, sürekli değişken) ve geri dönüşüm (faktör 4, sürekli değiş̧en) dahil edilmiştir.

\section{BULGULAR VE TARTIŞMA:}

\section{Bireylerin Genel Özellikleri}

Araştırma kapsamın görüşülen bireylerin ortalama yaşı 39.71, \%63.71'i erkek, \%73.11'i evli, \%82.77'si aktif olarak çalıştığı ve aylık ortalama 2,267.06 TL geliri olduğu belirlenmiştir. Bireylerin \%55.87'si lise ve altı mezun olduğu belirlenmiştir (Çizelge 1). Benzer çalışmalarda bireylerin sosyo-ekonomik yapılarında benzerlik gösteren çalışmalara rastlamak mümkündür. Aracıoğlu ve Tatlıdil (2009), İzmir ilinde yaptıkları çalışmalarında tüketicilerin \%51.39'u erkek, yaş aralığını en yoğun olduğu aralık 25-34 yaş (\%42.5) ve aktif olarak çalışanların oranı \%81.7'dir.

Bireylerin eşlerinin eğitim durumları incelendiğinde \%53.00'ü lise ve üstü eğitim gördüğü ancak \%20.63'ü aktif olarak çalıştı̆̆ Çizelge 1'den anlaşılmaktadır.

Çizelge 1. Bireylerin Bazı Sosyo-Demografik Özellikleri

\begin{tabular}{|c|c|c|c|c|c|}
\hline Grup & ve Açıklaması & Frekans & $\%$ & Ortalama & $\begin{array}{l}\text { Standart } \\
\text { Sapma }\end{array}$ \\
\hline & Bilinçli bireyler:1 & 266 & 69.45 & & \\
\hline Bağımlı Değişken (Y) & $\begin{array}{l}\text { Bilinç seviyesi düşük olan } \\
\text { bireyler:0 }\end{array}$ & 117 & 30.55 & - & 0.461 \\
\hline Yaş & & & & 39.71 & \\
\hline Yaş Grubu 1 (YAS1) & $\begin{array}{l}\text { eğer bireyler } 30 \text { ve altı yaş } \\
\text { grubunda ise: } 1\end{array}$ & 79 & 20.63 & & 0.405 \\
\hline & değil ise: 0 & 304 & 79.37 & & $=$ \\
\hline & bireyler 31-40 yaş grubunda & 122 & 3185 & & \\
\hline Yaş Grubu 2 (YAS2) & ise: 1 & 122 & & & 67 \\
\hline 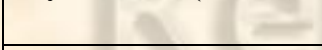 & değil ise: 0 & 261 & 68.15 & & \\
\hline Yaş Grubu 3 (YAS3) & $\begin{array}{l}\text { bireyler } 41 \text { ve üzeri yaş } \\
\text { grubunda ise: } 1\end{array}$ & 188 & 49.09 & $-2-2$ & 0.501 \\
\hline & değil ise: 0 & 195 & 50.91 & & \\
\hline Bireylerin Ortalama Ay & Geliri (ay/TL) & & & $2,267.06$ & \\
\hline Gelir Grubu (GELIR) & $\begin{array}{l}\text { bireylerin aylı geliri } 2.500 \\
\text { ay/TL'nin üstünde ise: } 1\end{array}$ & 110 & 28.72 & & 0.453 \\
\hline & 2.500 ve altında ise: 0 & 273 & 71.28 & & \\
\hline Cincivet (CINSIYET) & Kadın:0 & 139 & 36.29 & & 0.481 \\
\hline 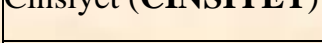 & Erkek:1 & 244 & 63.71 & & 0.401 \\
\hline Medeni Durum (MD) & Bekar:0 & 103 & 26.89 & & 0.444 \\
\hline Wiedent Durum (IMD) & Evli:1 & 280 & 73.11 & & 0.444 \\
\hline Eğitim Durumu (ED ) & $\begin{array}{l}\text { Lise ve lise altı Mezunu } \\
\text { Olanlar:0 }\end{array}$ & 214 & 55.87 & & 0.497 \\
\hline & Lise üstü Mezunu Olanlar:1 & 169 & 44.13 & & \\
\hline
\end{tabular}




\begin{tabular}{|c|c|c|c|c|c|}
\hline \multirow[b]{2}{*}{$\begin{array}{l}\text { Çalışma Durumu } \\
\text { (CALISM) }\end{array}$} & Çalışıyor:1 & 317 & 82.77 & & \multirow[b]{2}{*}{0.378} \\
\hline & $\begin{array}{l}\text { Çalışmıyor (Emekli, İşsiz, İş } \\
\text { arıor, öğrenci): } 0\end{array}$ & 66 & 17.23 & & \\
\hline \multirow[b]{2}{*}{$\begin{array}{l}\text { Eşinin Eğitim Durumu } \\
\text { (ESED) }\end{array}$} & Lise üstü Mezunu Olanlar:1 & 203 & 53.00 & & \multirow[b]{2}{*}{0.500} \\
\hline & $\begin{array}{l}\text { Lise ve lise alt } \text { Mezunu } \\
\text { Olanlar:0 }\end{array}$ & 180 & 47.00 & & \\
\hline \multirow{2}{*}{$\begin{array}{l}\text { Eşinin Çalışma Durumu } \\
\text { (ESCALISSM) }\end{array}$} & Çalışıyor:1 & 79 & 20.63 & & \multirow[b]{2}{*}{0.405} \\
\hline & $\begin{array}{l}\text { Çalışmıyor (Emekli, İşsiz, İş } \\
\text { arıyor, öğrenci):0 }\end{array}$ & 304 & 79.37 & & \\
\hline \multicolumn{4}{|c|}{ Hanedeki Fert Sayısı (FERT) } & 4.55 & \\
\hline \multicolumn{6}{|c|}{ Tasarruf (faktör 1, sürekli değişken) (F1) } \\
\hline \multicolumn{6}{|c|}{ Çevre bilinci ve duyarlılığı (faktör 2, sürekli değişken) (F2) } \\
\hline \multicolumn{6}{|c|}{ Satın alma bilinci (faktör 3, sürekli değişken) (F3) } \\
\hline \multicolumn{6}{|c|}{ Geri dönüşüm (faktör 4, sürekli değişken) (F4) } \\
\hline
\end{tabular}

\section{Bireylerin satın almadaki bilinç düzeyleri}

Bireylerin satın aldıkları ürünlerde çevre bilincini ölçe bilmek için bir takım sorular sorulmuş ve sorular çevre duyarlılığına göre puanlanmış böylelikle bireylerin bilinç düzeyleri belirlenmesi hedeflenmiştir. Çizelge 2'de bireylere sorulan satın almada ki çevre duyarlıkları ile ilgili sorular ve cevapları verilmiştir.

Bireylerin \%90.60'nın çevre kirliliğine karşı duyarlı olduğu belirlenmiştir. Bireylerin \%68.93'ü çevre ile ilgili haberleri izlemekte, \%78.07'si çöplerini atarken ayrıştırarak atmaya dikkat ederken, \%80.16'sı satın aldıkları ürünlerin üzerindeki ambalaj ya da etiketteki bilgileri okuduğu Çizelge 2'den anlaşılmaktadır. Yani bireylerin çevre duyarlılığının satın almada yüksek olduğunu bu sonuçlar neticesinde söylemek mümkündür. Benzer sonuçları Aracıoğlu ve Tatlıdil (2009)'in araştırmalarında da rastlanmıştır. İzmir ilinde yapılan araştırmadaki tüketicilerin \%72.5'i çöplerini atarken ayrıştırmaya dikkat ettiği ve \%51.9'nun ambalaj ya da etiket okuduğu sonucunu bulmuşlardır. Ancak gençler üzerinde araştırma yapan Tayfun ve Öçlü (2016), öğrencilerin \%90.6'sının çevresel ürün satın almayı tercih etmediğini belirlemiştir.

Bireylerin geri dönüşümü olan maddeleri tanıdığını belirlemek üzere 6 kategoride ürün sorulmuştur. Bireylerin \%22.98'i metal kutuların, \%26.37'si ampullerin, \%14.88'i cam şişelerin, \%18.28'i tüm plastik kutuların ve \%39.69'u naylon poşetlerin geri dönüşümünün olmadığını, olsa da doğada çok uzun yıllarda kaybolduğunu biliyor. Çizelge 2'ye göre bireylerin \%42.30'u dergi-kitapların ve \%51.96'sı gazetelerin geri dönüşümünün olduğu bilgisine sahiptir.

Bireylerin çevre kirliliğine ilişkin sınıflandırmadaki önem seviyesi belirlemek için üçlü likert ölçeği kullanılmıştır. Sınıflandırma hava, su, toprak kirliliği şeklinde yapılmıştır. Çizelge 2'den de anlaşılacağı üzere bireylerin büyük bir kısmı hava, su ve toprak kirliliğinin kısacası hepsini çok önemli bulmuşlardır. Bu da bireylerin çevre kirliliğine karşı farkındalık sahibi; ancak korunması gereken bilgiler hakkında bilgi eksiliğinin olduğunun bir göstergesidir. Paralel bir sonucu Türkiye'nin en batısında bulunan İzmir ilinde araştırma yapan Aracıoğlu ve Tatlıdil (2009), bulmuşlardır. Araştırmada tüketicilerin \%69.0’u hava, toprak ve su kirliliğinin hepsinin çevresel kirlilik olarak görmektedir.

Çizelge 2. Bireylerin satın almadaki bilinç düzeyleri için sorulan sorular ve soruların puanları

\begin{tabular}{|c|c|c|c|c|}
\hline & \multicolumn{2}{|c|}{ Evet (1 puan) } & \multicolumn{2}{|c|}{ Hayır (0 puan) } \\
\hline & $\mathbf{F}$ & $\%$ & $\mathbf{F}$ & $\%$ \\
\hline Cevre Kirliliği konusuna önem verme & 347 & 90.60 & 36 & 9.40 \\
\hline Çevreye ilişkin haberleri izleme & 264 & 68.93 & 119 & 31.07 \\
\hline Çöp ayrıştırması & 299 & 78.07 & 84 & 21.93 \\
\hline $\begin{array}{l}\text { Ambalaj veya etiket üzerindeki bilgileri } \\
\text { okuma }\end{array}$ & 307 & 80.16 & 76 & 19.84 \\
\hline \multicolumn{5}{|l|}{ Geri dönüşümü olan maddeler } \\
\hline \begin{tabular}{|l}
\multicolumn{1}{|c|}{ Metal Kutular } \\
(Evet diyenler:0, \\
Hayır diyenler:1 puan almıştır)
\end{tabular} & 295 & 77.02 & 88 & 22.98 \\
\hline Ampuller & 282 & 73.63 & 101 & 26.37 \\
\hline
\end{tabular}




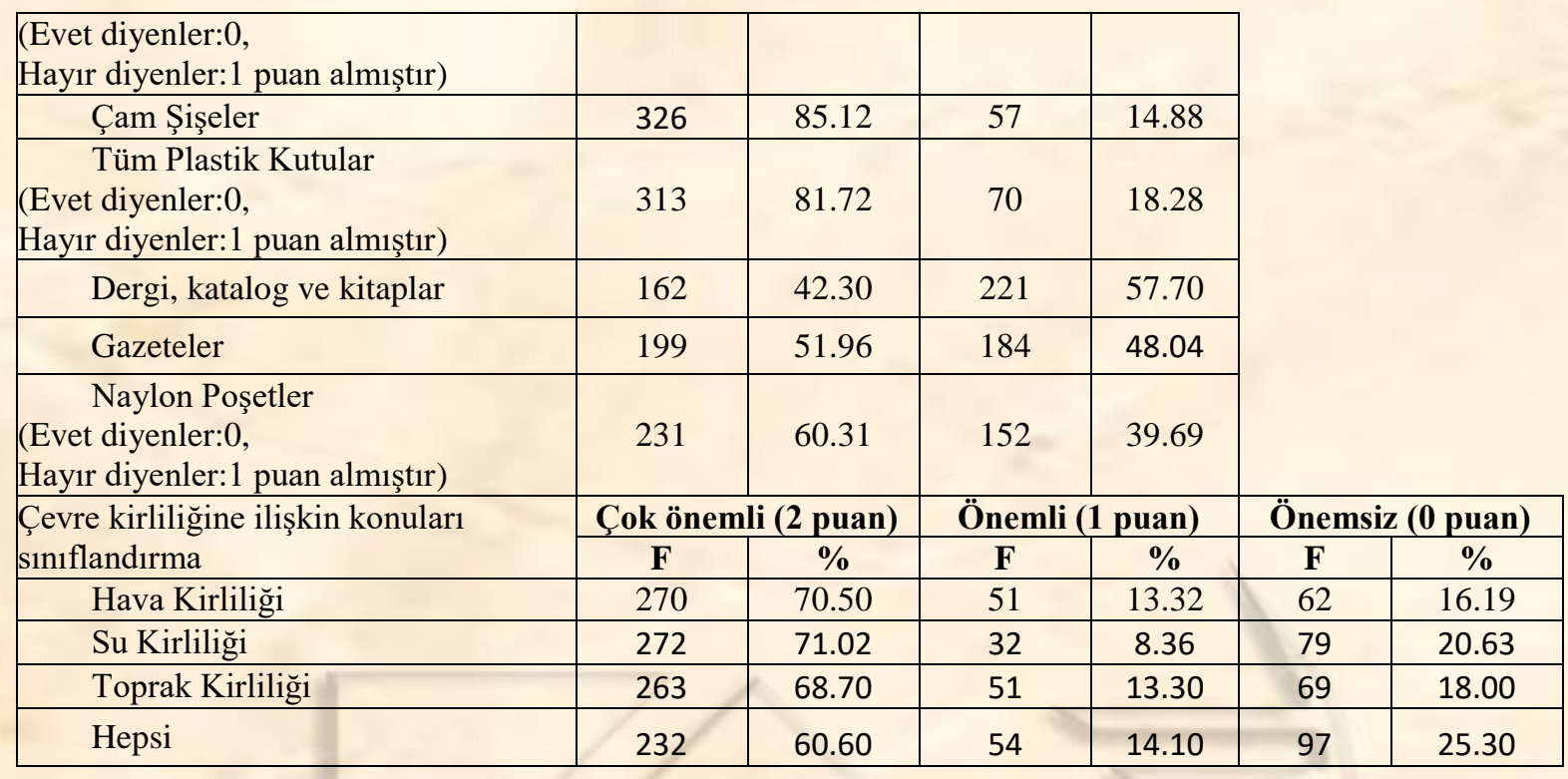

\section{Bireylerin Satın Almadaki Tutum ve Davranışı}

Bireylerin bir ürün satın alırken dikkat ettikleri 20 kriteri özetleye bilmek için faktör analizi yapılmıştır. Analiz sonucunda 20 kriter; tasarruf, çevre bilinci ve duyarlılığı, satın alma bilinci ve geri dönüşüm olmak üzere 4 faktör altında toplanabileceği anlaşılmıştır. İlk faktör toplam varyansın \%18.01'ini, ikinci faktör \%17.31'ni, üçüncü faktör \%13.64'nü ve dördüncü faktör \%12.19'nu ve birikimli varyans, toplam varyansın \%67.12'sini açıkladığ belirlenmiştir.

Faktör analizinin kabulü için KMO testi sonucuna bakılır. Bu değerin 0.600 'dan büyük olması modelin anlamlılı̆̆ını belirler çünkü bire yaklaştıkça modelin açıklayıcılı̆̆ı artmaktadır (Tabachnick ve Fidell, 1996; Kalayc1, 2010). Nitekim Çizelge 3'de göründüğ̈̈ üzere araştırmanın model açıklayıcılığ 10.926 olması örneklemin yüksek ve modelin kabulü anlamına gelmektedir (Field, 2000; Topçu, 2006; Keleş, 2007, Yılmaz, 2009; Kızıloğlu ve ark., 2013).

Ölçeğin güvenirliği Cronbach’s Alpha ile test edilmiş ve güvenilirlik kat sayısı 0.918 olarak hesaplanmıştır.

Alkaya ve ark. (2016), öğrencilerin çevre duyarlıı̆̆ını belirlemek için faktör analizi yapmışlardır. Analiz sonucunda KMO değerini 0.836 , faktörlerin açıklayıcı varyansını $\% 60.80$ ve 3 faktör yükü bulmuşlardır.

Benli ve ark. (2017), çalışan bireylerin yeşil ürün satın alımındaki tutumları faktör analizi ile test etmişler ve analiz sonucuna göre; Cronbach's Alpha testinin sonucu 0.717, KMO değerini 0.793 ve 4 faktör yükü tespit etmişlerdir.

Korkmaz ve ark. (2017), öğrencilerin çevresel tutumlarını 11 yargı ifadesini faktör analizi ile test etmiş ve analiz sonucuna göre; Cronbach's Alpha testinin sonucu 0.822, açıklanan toplam varyansı \%64.31 ve 2 faktör yükü olarak belirlemişlerdir.

Onurlubaş ve ark. (2017a), tüketicilerin sosyal medyanın satın almada ki etkilerini faktör analizi ile davranışların yükleri belirlenmeye çalışılmıştır. Analiz sonucunda; Cronbach's Alpha testinin sonucu 0.500, açıklanan toplam varyansı $\% 68.73$ ve 2 faktör yükü olarak tespit edilmiştir.

Ziraat alanında yapılmış diğer çalışmalarda elde edilen sonuçlar incelendiğinde; Çelik (2012)'nin çalışmasında KMO değeri 0.717 ve önemli faktör sayısı 5 bulunurken, faktörlerin varyansı açıklama oranı \%69.32 elde edilmiştir. Çelik ve Tatlıyer (2016)'in faktör analizi çalışmasında 13 değişken 4 faktörle \%75.53'lik varyansı açıklama oranı ile belirlenebilmiştir. Kızıloğlu ve Kızılaslan (2015) bireylerin süt ve süt ürünleri satın alma yerini belirlerken dikkat ettikleri 16 özelliği 3 değişken halinde özetlemiş ve KMO değerini 0.884 olarak hesaplamıştır.

Çizelge 3. Bireylerin Çevre Duyarlılığı İçin Satın Almadaki Tutum ve Danışları İçin Anlamlılık Test Sonuçları 


\begin{tabular}{|l|l|}
\hline Khi kare & 4009.783 \\
\hline df & 190 \\
\hline Önem seviyesi & 0.000 \\
\hline
\end{tabular}

1. Faktör yükünde yani tasarruf başlığı altında 4 değişkeni, 2. Faktör yükünde yani çevre bilinci ve duyarlılığı başlığı altında 7 değişkeni, 3. Faktör yükünde yani satın alma bilinci başlığı altında 5 değişkeni, ve son faktör yükünde yani geri dönüşüm başlığı altında 4 değişkeni toplana bilenebileceğini dönüşümlü faktör yükleri matrisi göstermiştir (Çizelge 4).

Çizelge 4. Bireylerin Çevre Duyarlılığı İçin Satın Almadaki Tutum ve Danışları İçin Dönüşümlü Faktör Yükleri (Rotated Component Matrix)

\begin{tabular}{|l|c|c|c|c|c|}
\hline \multicolumn{5}{|c|}{ Faktör 1: tasarruf } \\
\hline Kalorifer açık iken kapı ve pencereyi açık tutmamak & $\mathbf{0 . 7 8 1}$ & 0.184 & 0.086 & 0.139 & 0.038 \\
\hline Bulunduğu ortamda ısı ve enerji tasarrufuna dikkat etme & $\mathbf{0 . 7 5 4}$ & 0.372 & 0.169 & 0.100 & -0.080 \\
\hline \multicolumn{1}{|c|}{ Faktör 2: çevre bilinci ve duyarlı1lı̆ı } & & & \\
\hline
\end{tabular}

\section{Bireylerin Çevreye Karşı Satın Almada Bilinç Seviyesini Etkileyen Faktörlerin Belirlenmesi}

Bireylerin çevreye karşı bilinçli olarak satın alma olasılığını etkileyen bazı faktörlerin belirlenmesi için binary logit analizi uygulanmıştır. Böylelikle bilinçli satın alma olasılığı, bilinçsiz satın alma olasılığı ile oranlayıp, son zamanlarda tehdit boyutuna ulaşan çevre kirliliğine karşı bireylerin bilinçli satın almasını etkileyen faktörler istatistiksel olarak belirlenmiştir. Çizelge 5'de analiz sonuçları verilmiştir.

Çizelge 5. Bireylerin Çevreye Karşı Bilinçli Satın Almayı Etkileyen Faktörlerin Binary Logit Analiz Sonucu 


\begin{tabular}{|c|c|c|c|c|c|}
\hline & Kat Sayı & Standart Hata & $\mathrm{z}$ & $|\mathbf{z}|>\mathbf{Z}$ & Marjinal Etki \\
\hline sabit & $2.00963 * *$ & 1.02452 & 1.96 & 0.0498 & 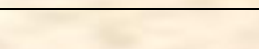 \\
\hline CINSIYET & -0.31136 & 0.28187 & -1.10 & 0.2693 & -0.05984 \\
\hline YAS1 & $-1.84945^{*}$ & 0.95195 & -1.94 & 0.0520 & $-0.36980 * *$ \\
\hline YAS2 & $-1.62539 *$ & 0.97462 & -1.67 & 0.0954 & $-0.30987^{*}$ \\
\hline YAS3 & -1.61514 & 1.02274 & -1.58 & 0.1143 & $-0.28574^{*}$ \\
\hline MD & -0.12308 & 0.40301 & -0.31 & 0.7601 & -0.02373 \\
\hline ED & $0.60402 * *$ & 0.28104 & 2.15 & 0.0316 & $0.11627 * *$ \\
\hline CALISMA & -0.07991 & 0.34563 & -0.23 & 0.8171 & -0.01542 \\
\hline ESCALISM & 0.31065 & 0.33680 & 0.92 & 0.3563 & 0.05873 \\
\hline ESED & 0.44393 & 0.30215 & 1.47 & 0.1418 & 0.08676 \\
\hline FERT & 0.04826 & 0.05906 & 0.82 & 0.4139 & 0.00940 \\
\hline GELIR & $0.52851 *$ & 0.28227 & 1.87 & 0.0612 & $0.09899 * *$ \\
\hline F1 & $0.34246 * * *$ & 0.12893 & 2.66 & 0.0079 & $0.06671 * * *$ \\
\hline $\mathrm{F} 2$ & 0.18005 & 0.12574 & 1.43 & 0.1522 & 0.03507 \\
\hline F3 & 0.04572 & 0.11936 & 0.38 & 0.7017 & 0.00891 \\
\hline $\mathrm{F} 4$ & $-0.22838^{*}$ & 0.11993 & -1.90 & 0.0569 & $-0.04449^{*}$ \\
\hline \multicolumn{6}{|c|}{ Not: $* * *, * *, *=\Rightarrow$ Önem seviyesinde temsili $\% 1, \% 5, \% 10$} \\
\hline \multicolumn{6}{|c|}{$\begin{array}{lr}\text { log likelihood: }-219.76054 & \text { Chi kare [16 d.f.]: } 31.90498 \\
\text { Seviyesi: } 0.01029 & \text { McFadden } R^{2}: 0.0676776 \\
\end{array}$} \\
\hline
\end{tabular}

Analiz sonucunda; \%5 önem seviyesinde bireylerin satın almada çevreye duyarlılığı ile gelir ve eğitim seviyesi arasında pozitif bir ilişki olduğu belirlenmiştir. Yani bireylerin eğitim seviyesindeki bir birimlik artış satın almadaki bilinçliliği \%11 artırması beklenmektedir. Gelirdeki bir birimlik artış bilinçlenmeyi \%10 artırma olasılığı söz konusudur.

Faktör 1 (tasarruf) \%1 önem seviyesinde ve Faktör 4 (geri dönüşüm) \%10 önem seviyesinde satın almayla pozitif ilişkili olduğu belirlenmiştir.

Bireylerin yaşları küçüldükçe çevreye olan duyarlıkları daha fazla olduğu istatistiksel olarak belirlenmiştir.

Bireylerin yaşlarının genç olması, eğitim seviyesinin artması ve gelir sevisinin yükselmesi satın almadaki bilinç seviyesi ile pozitif ilişkili olduğu araştırma sonucunda ortaya konulmuştur.

Çabuk ve ark. (2008), tüketicilerin yeşil ürün satın almasını etkileyen sosyo-demografik özelliklerin belirlenmesi için çoklu regrasyon analizi ile test etmiş, analiz sonucunda cinsiyet, medeni durum, yaş grupları, eğitim durumu ve gelir grupları arasında pozitif bir ilişki bulmuşlar.

Aracıoğlu ve Tatlıdil (2009), tüketicilerin eğitim durumu ile çevre korunması arasında khi kare analizi sonucunda pozitif bir ilişki bulmuştur.

Yeniçeri (2009), araştırmasında öğrencilerin çevreye karşı bilinçli ve satın almalarında cinsiyet, eğitim durumlarının ve gelirlerinin pozitif bir etkisi olduğunu bulmuştur.

Alkaya ve ark. (2016), yeşil ürün satın almayı etkileyen faktörlerin belirlenmesinde; faktör analizi sonucunda elde ettikleri yükleri regresyon analizinde bağımsız değişken olarak kullanmışlar ve kişisel duyarlılık yükü ve ekolojik duyarlılık yükü ile satın alma arasında pozitif bir ilişki tespit etmişlerdir.

Onurlubaş ve ark. (2017b), tüketicilerin yeşil ürün satın alması ile cinsiyetleri, gelirleri, yaşları ve medeni durumları arasında khi kare analizi sonucunda anlamlı ilişki bulunmuştur. 


\section{SONUC VE ÖNERILER:}

İnsanoğlunun hayatını tehdit edecek ve gelecek nesillerin sağlıklı bir hayat kalmayacak bir boyuta gelen çevre kirliği olayı çevre konularının önemini artırmıştır. Bu araştırmada tarımda önemli bir yeri olan Tokat ili kentsel alanında yaşayan bireylerin çevre duyarlılığının satın almadaki boyutu incelenmiştir. Bireylerin sosyo-demografik özellikleri incelendikten sonra, satın almadaki bilinç düzeylerini belirlemek için bir takım sorular sorulmuş ve soruların puanlama sistemi uygulanmıştır. Bu puanlama sonucu bireylerin \%69.45'i bilinç seviyesi yüksek olarak belirlenmiştir.

Bireylerin çevre konularına önem verdiği, çevreye ilişkin haberleri izlediği, çöplerini ayrıştırma konusunda önem gösterdikleri ve ambalajlı ürünlerin etiketlerini okuma hassasiyeti olduğu gözlenmiş̧ir. Bireylerin geri dönüşümlü ürünleri bildiği tanıdığı söylenebilir. Yani bireylerin çevre konularında bilinçli olma potansiyeli olduğu araştırma sonuçları doğrultusunda söylenebilir.

Bireylerin çevreye ilişkin satın almada tutum ve davranışlarını belirlemek üzere 20 yargı cümlesi sorulmuştur. Faktör analizi yardımıyla bu değişkenler 4 faktör altında toplanarak satın almayı etkileyen faktörlerin belirlenmesi için kullanılan binary logit analizinde açıklayıcı değişken olarak kullanılmıştır.

Analiz sonucunda; \%5 önem seviyesinde bireylerin satın almada çevreye duyarlılı̆̆ arasında pozitif bir ilişki olduğu belirlenmiştir. Yani genel olarak bilinen gelir seviyesi ve eğitim durumu yüksek olması bilinç seviyesini yüksek olması yargısı bu araştırma ile istatistiki olarak doğrulanmıştır.

Faktör 1 (tasarruf) \%1 önem seviyesinde ve Faktör 4 (geri dönüşüm) \%10 önem seviyesinde satın almayla pozitif ilişkili olduğu belirlenmiştir.

Bireylerin yaşları küçüldükçe çevreye olan duyarlıkları daha fazla olduğu istatistiksel olarak belirlenmiştir. Yani genç bireylerin çevre duyarlılı̆̆ı ileriki yaşlara göre daha yüksek olduğu söylenebilir.

Özetle Bireylerin yaşlarının genç olması, eğitim seviyesinin artması ve gelir sevisinin yükselmesi satın almadaki bilinç seviyesi ile pozitif ilişkili olduğu araştırma sonucunda ortaya konulmuştur. Çevre ile ilgili kurum ve kuruluşlar çevreci politikalar uygularken; bireylerin yaşı, eğitim seviyesi ve gelir düzeyini dikkate alarak politika geliştirir ya da uygularsa daha kalıcı sonuçlarla karşılaşacağı bu araştırma sonucunda söylenebilir.

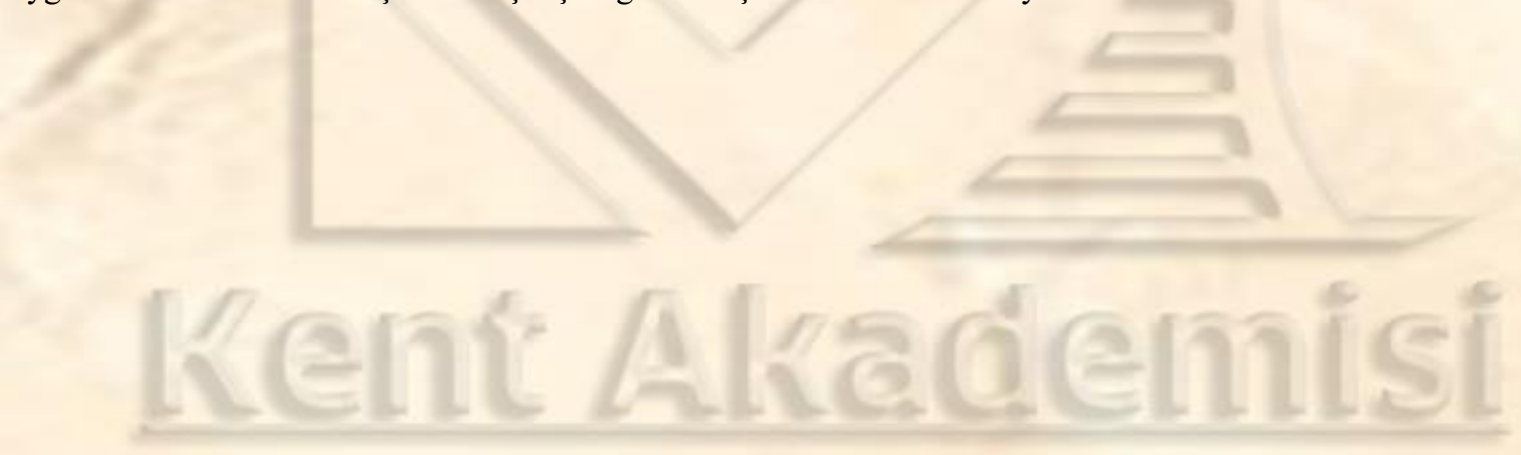




\section{KAYNAKÇA:}

Alkaya, A, Çoban, S , Tehci, A , Ersoy, Y . (2016). Çevresel Duyarlılığın Yeşil Ürün Satın Alma Davranışına Etkisi: Ordu Üniversitesi Örneği. Erciyes Üniversitesi İktisadi ve İdari Bilimler Fakültesi Dergisi, 0 (47), 121-134.

Aracıoğlu, R., Tatlıdil, R., (2009). Tüketicilerin Satın Alma Davranışında Çevre Bilincinin Etkileri. Ege

Akademik Bakış / Ege Academic Review, 9 (2): 435-461.

Armağan, E , Karatürk, H . (2014). Yeşil Pazarlama Faaliyetleri Çerçevesinde Aydın Bölgesindeki

Tüketicilerin Çevreye Duyarlı Ürünlerı Kullanma Eğilimlerini Belirlemeye Yönelik Bir Araştırma. Organizasyon ve Yönetim Bilimleri Dergisi, 6 (1), 1-17.

Benli T. \& Karaosmanoğlu K. \& Taş Ö. (2017), Çalışan Bireylerin Yeşil Ürün Reklamlarına Yönelik

Tutumlarını Etkileyen Faktörlerin Demografik Özelliklerine Göre Farklılıkları, BMIJ, 5(4): 235-256.

Biswas, A., Roy, M., (2015). Green Products: An Exploratory Study On The Consumer Behaviour İn

Emerging Economies Of The East. Journal Of Cleaner Production 87 , 463-468.

Buğday, E , Babaoğul, M . (2016). Bilinçli Tüketim Kavramının Boyutları: Bilinçli Tüketim Davranışının

Yeniden Tanımlanması. Sosyoekonomi, 24 (30), 187-206.

Çabuk, S., Nakıboğlu, B., Keleş, C. (2008). Tüketicilerin Satın Alma Davranışlarının Sosyo-Demografik

Değişkenler Açısından İncelenmesi. Ç.Ü. Sosyal Bilimler Enstitüsü Dergisi, 17(1), s. 85-102.

Çelik, Ş. 2012. Türkiye deki İllerin Bitkisel Üretiminin Faktör Analizi ile İncelenmesi. Yüzüncü Yıl

Üniversitesi Tarım Bilimleri dergisi, 22(2), 69-76.

Çelik, Ş. ve A.Tatlyyer 2016. Ranking of provinces in Turkey according to numbers of animals through factor

analysis. International Journal of Development Research, 6(2), 6620-6626.

Dölekoğlu C. Yurdakul O. (2004) Adana İlinde Hane Halkının Beslenme Düzeyleri ve Etkili Faktörlerin Logit

Analizi İle Belirlenmesi. Akdeniz İ̈BF Dergisi, 8: 62-86.

Duru, M , Şua, E . (2013). Yeşil Pazarlama ve Tüketicilerin Çevre Dostu Ürünleri Kullanma Eğilimleri. Düzce

Üniversitesi Ormanc1lık Dergisi, 9 (2), 126-136.

Field,A. 2000. Discovering Statistics Using SPSS for Windows. London: SAGE Publication.

Kalaycı Ş. (2010) SPSS Uygulamalı Çok Değişkenli İstatistik Teknikleri. BRC Matbaacılık, Ankara.

Karpati L., Szakal Z. (2009) Marketing Characteristics of Tokaj Wine Specialities Based on Factor and Cluster Analyses. Applied Studies in Agribusiness and Commerce - APSTRACT Agroinform Publishing House, Budapest. p: 93-102.

Keleş, C. 2007. Yeşil Pazarlama Tüketicilerin Yeşil Ürünleri Tüketme Davranışları ve Yeşil Ürünlerin Tüketiminde Kültürün Etkisi ile İlgili Bir Uygulama. Sosyal Bilimler Enstitüsü, İşletme ABD, (Yüksek Lisans Tezi).

Khare, A. (2015) "Antecedents To Green Buying Behaviour: A Study On Consumers İn An Emerging Economy", Marketing Intelligence \& Planning, Vol. 33 Issue: 3, Pp.309-329.

Kızıloğlu R., Kızılaslan H. (2013) Consumer behaviors on food purchasing places: A case study of red meat consumption in Turkey, Research\&Reviews in Biosciences (RRBS), ISSN : 0974 - 7532, 7 (11), 453-459.

Kızıloğlu R., Kızılaslan H., Gökçe C. (2013) Gaziosmanpaşa Üniversitesi Ziraat Fakültesi Öğrencilerinin Yeşil Gıda Ürünleri Hakkındaki Bilgi, Görüş ve Tutumları Üzerine Araştırma. Gaziosmanpaşa Bilimsel Araştırma Dergisi, 6, 19-30.

Kızıloğlu, R. ve H. Kızılaslan, 2015. TR 83 Bölgesinde Süt ve Süt Ürünleri Tüketiminde Tüketici Davranışlarını Etkileyen Faktörler Ve Talebinin Belirlenmesi. Tarımsal Ekonomi ve Politika Geliştirme Enstitüsü TEPGE, Yayin No: 274, ISBN: 978-605-9175-52-4.

Korkmaz, M., Atay, L., Yıldırım, M., (2017). Yeşil Ürün Satın Alma Davranışı, Kişilerarası Etkilenme Eğilimi ve Sosyal Etki Arasındaki İliş̧ki: Üniversite Öğrencileri Üzerine Bir Araştırma. Seyahat ve Otel İşletmeciliği Dergisi/ Journal of Travel and Hospitality Management 14 (3), 40-52.

Kurtuluş K. (2004) Pazarlama Araştırmaları (Genişletilmiş 7. Baskı). Literatür Yayınları, Yayın No: 114, s:397-418, İstanbul.

Liobikienè, G., Mandravickaite, J., Bernatonienė, J., (2015). Theory Of Planned Behavior Approach To Understand The Green Purchasing Behavior İn The EU: A Cross-Cultural Study. Ecological Economics Volume 125, Pages 38-46.

Maichum, K., Parichatnon, S., Peng, KC., (2016). Application of the Extended Theory of Planned Behavior Model to Investigate Purchase Intention of Green Products among Thai Consumers. Sustainability 8, 1077; 1-20

Medeiros, JF., Ribeiro JJD., Cortimiglia MN., (2016). Influence of perceived value on purchasing decisions of green products in Brazil. Journal of Cleaner Production 110, 158-169.

Ness M. (2000) Multivariate Techniques in Marketing Research. Curso de Especializacion Postuniversitaria en Marketing Agroalimentario, CHIEAM, Spain. 
Onurlubaş, E., Yıldız, E., Yıldız, S., Dinçer, D., (2017a). Tüketicilerin Yeşil Ürün Satın Alma Davranışlarını Etkileyen Faktörlerin Belirlenmesi: Bursa İli Örneği. III. IBANESS Congress Series - Edirne / Turkey, 04-05 Mart, s:281-290.

Onurlubaş, E., Yıldız, E., Yıldız, S., Dinçer, D., (2017b). Sosyal Medya Uygulamalarının Tüketici Satın Alma Davranışları Üzerindeki Etkileri: Facebook Örneği. III. IBANESS Congress Series - Edirne / Turkey, 04-05 Mart, s:291-297.

Suki, NM., (2016). Consumer Environmental Concern And Green Product Purchase İn Malaysia: Structural Effects Of Consumption Values. Journal Of Cleaner Production Volume 132, Pages 204-214.

Tabachnick B.G., Fidel S.L . (2001) Using Multivariate Statistics, 4th Edition, Boston.

Tayfun Özgüven, N., Öçlü, B. (2016). Çevreci Ürünlerin Tüketicilerin Satın Alma Kararlarındaki Yeri Üzerine Bir Uygulama. Niğde Üniversitesi İktisadi Ve İdari Bilimler Fakültesi Dergisi, 9(3), 185-198.

Tekin V.N. (2007) SPSS Uygulamalı Bilimsel Pazarlama Araştırmaları. Seçkin Yayıncılık, Ankara.

Topçu, Y. 2006. Süt Ürünlerinde Marka Rekabeti ve Tüketici Davranışları: Erzurum İli Örneği. Atatürk Üniversitesi Fen Bilimleri Enstitüsü, Tarım Ekonomisi ABD, (Doktora Tezi).

Türkmen, M., Sarıkaya, N., Saygılı, M . (2013). Öğrencilerin Çevresel Duyarlılık Düzeylerinin Satın Alma Davranışına Etkisi Üzerine Bir Araştırma: Sakarya Üniversitesi Örneği. Sosyal ve Beşeri Bilimler Dergisi, 5 (2), 238249.

Yadav, R., Pathak, GS., (2016). Young Consumers' İntention Towards Buying Green Products İn A Developing Nation: Extending The Theory Of Planned Behavior. Journal Of Cleaner Production Volume 135, Pages 732-739.

Yamane, T., (2001). Temel Örnekleme Yöntemleri. Çevirenler: Alptekin Esin, Celal Aydın, M. Akif Bakır, Esen Gürbüzsel, Literatür Yayıncılık, İstanbul.

Yaraş, E , Akın, E , Şakacı, B . (2012). Tüketicilerin Çevre Bilinci Düzeylerini Belirlemeye Yönelik Bir Araştırma. Öneri Dergisi, 9 (35), 117-126.

Yeniçeri, T . (2009). Tüketicilerin Çevre Bilinci ve Çevreye Duyarlı Satın Alma Davranışlarına Yönelik Bir Pilot Araştırma. Sosyal Ekonomik Araştırmalar Dergisi, 9 (17), 310-326.

Yıldız, E., Barut, A. (2016) Yeşil Pazarlama Karması, Çevresel Kaygı ve Çevresel Bilginin Yeşil Ürün Satın Alma Davranış1 Üzerindeki Etkisi. GÜSBEED, Gümüşhane Üniversitesi Sosyal Bilimler Enstitüsü Elektronik Dergisi, 7 (16), 158-171.

Yılmaz, V. 2009. Türkiye Akarsuları Su Kalitesi Parametrelerinin Çok Değişkenli İstatistiksel Analiz Yöntemleriyle İncelenmesi. Selçuk Üniversitesi Fen Bilimleri Enstitüsü, İnşaat Mühendisliği ABD, (Yüksek Lisans Tezi). 